\title{
Hidden Treasures: Institute of Physiology collection
}

\author{
A cache of beautiful nineteenth-century German scientific devices that has survived many \\ misfortunes now needs a new home, reports Alison Abbott.
}

The ingenious 1847 'Multiplikator' was the finest instrument of Emil du Bois-Reymond (1818-96), the first scientist to measure current flowing in nerves and muscles in the working human body. Built in Germany, in collaboration with instrument-maker Johann Georg Halske, the device's sleek, high-precision form presages the Bauhaus aesthetic of eight decades later. With the Multiplikator, du Bois-Reymond consolidated his position as a founder of modern electrophysiology.

The 1840s launched electrophysiology - some 75 years after Luigi Galvani made dead frog muscle twitch by applying electric current to a nerve. For most of his life Galvani fought to persuade sceptical colleagues that the apparent quackery of 'animal magnetism' and 'animal electricity' was a reality. He was long dead before the instrument bearing his name, the galvanometer, was invented. And it was du Bois-Reymond who rendered the galvanometer sensitive enough to detect the tiny physiological currents in living tissues; the currents induce magnetic waves that deflect a compass needle.

Around the Multiplikator's core, du BoisReymond wound more than 10,000 coils of thin wire to magnify the effect of the current. He connected the wires' ends to two vessels of salt solution. The Multiplikator operator — usually du Bois-Reymond himself — held two wooden batons while dipping one finger of each hand into the salt baths to close the circuit. He clenched one arm tightly, keeping the other relaxed. The transient negative electrical potential induced around the tensed muscle caused a current to flow between his arms, and through the entire circuit. The current's strength was revealed by the angle of the needle's deflection. To reduce resistance in his body, du Bois-Reymond worked bare-chested. To generate the strongest possible currents, the former competitive gymnast trained obsessively in a gym he built in his home.

It was a time when scientists took aesthetics seriously. du Bois-Reymond photographed his brother operating the Multiplikator (pictured), then turned the image into an engraving of Apollo, the Greek god of the arts, who embodies perfect male beauty.

Berlin was a major centre for science in the nineteenth century. Many of its most successful researchers were students at the Institute of Anatomy at the Friedrich Wilhelm University (now Humboldt University). These included

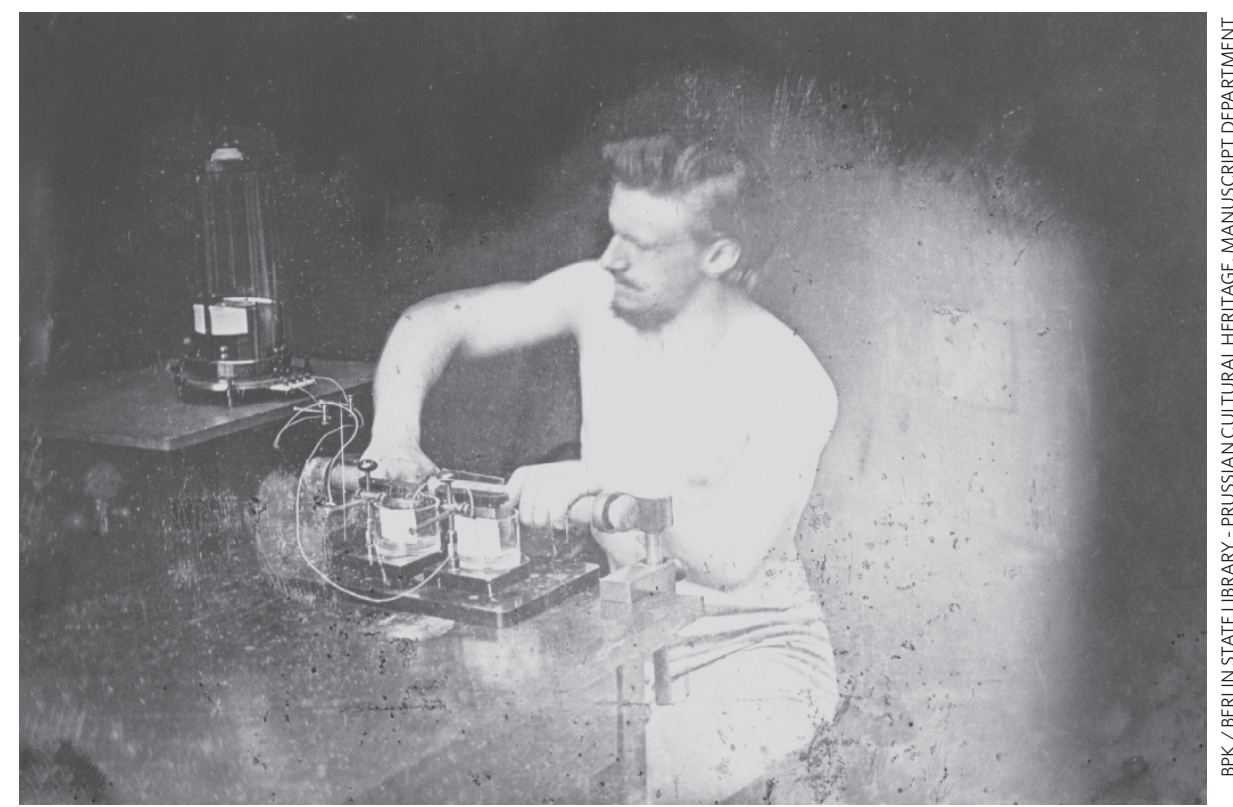

The Multiplikator, one of the fine examples of instrument craftsmanship in the Johannes Müller collection.

du Bois-Reymond as well as the physicist and physiologist Hermann von Helmholtz, the zoologist and artist Ernst Haeckel, and Werner von Siemens. Siemens helped to develop the Multiplikator before forming a telegraphic company in 1847 , the forerunner of today's Siemens electronics behemoth. He took Halske with him, a blow to the many Berlin scientists for whom the artisan had crafted unique physiological instruments.

By the late 1840s, the institute had a major collection of instruments, and it added more over the next few decades. When du Bois-Reymond was made director of a new, purpose-built Institute of Physiology in 1877, he displayed many of the instruments in its foyer. A year later, some of them were destroyed in a fire.

That was just the start of the collection's misfortunes. Having survived the Nazi period, the institute found itself in the Russian sector of occupied Berlin in 1945. Over the next 50 years the increasingly decrepit and destitute organization had more than 20 directors.

The historical instruments were regularly plundered for parts to build new gadgets for sexier sciences, notably biochemistry. When the institute's lecture theatre was reconstructed in the late 1950s, many of the glass cabinets in which the collection had been stored disappeared, to be rediscovered when the building's attic was cleared out in 1975. Those instruments that were not beyond rescue were cleaned and renovated, and displayed for the first time during the celebrations of the institute's centenary, in 1977.

After Berlin was reunified in 1990, the university physiology department had to move again - to a building that is now being sold by the cash-strapped organization Charité, a recent amalgamation of Berlin's eastern and western medical university faculties. Despite its chequered past, the instrument collection still comprises more than 200 important objects, including Helmholz's beautiful series of brass resonators and other devices built for his seminal work on physiological acoustics. Now named after the great experimental anatomist Johannes Müller, it also boasts many switching contraptions that delivered controlled pulses of electricity to the biological preparations and chymographs that recorded contractions of prepared muscles by scratching the smoked surface of a slowly revolving drum. First though, the collection needs to secure a new home. Alison Abbott is Nature's senior European correspondent.

See www.charite.de/ch/physio/hi/start.html for details. For more Hidden Treasures see www. nature.com/nature/focus/hiddentreasures. 